Valóságos könyvtár - könyvtári valóság. Könyvtár- és információtudományi tanulmányok 2020. Szerk. Kiszl Péter, Boda Gáborné Köntös Nelli.

Budapest, ELTE BTK Könyvtár- és Információtudományi Intézet. 2021. 57-74.

\title{
A KÖNYVTÁR- ÉS INFORMÁCIÓTUDOMÁNY, VALAMINT A KÖNYVTÁROSKÉPZÉS VÁLASZAI A GAZDASÁGI, TÁRSADALMI ÉS TECHNOLÓGIAI KIHÍVÁSOKRA
}

\author{
KISZL PÉTER
}

ELTE BTK KITI, intézetigazgató egyetemi docens

\section{TARTALMI ÖSSZEFOGLALÓ}

2019-ben ünnepelte 70 éves jubileumát a magyar egyetemi könyvtárosképzés és vele együtt az ELTE BTK Könyvtártudományi Tanszéke. Ebből az alkalomból áttekintjük, milyen fontosabb eredményeket tudhat magáénak a diszciplína legnagyobb hazai oktató- és kutatóhelye, a ma Könyvtár- és Információtudományi Intézetként, két tanszékkel (Könyvtártudományi Tanszék és Információtudományi Tanszék), valamint önálló szakkönyvtárral múködő intézmény, ahol lehetôség nyililk valamennyi felsőfokú képzési formában (alapképzés, mesterképzés, osztatlan tanárképzés, doktori képzés) végzettséget szerezni. A tanulmány kitér a gazdasági, társadalmi és technológiai környezet által elóidézett kihívásokra, majd ismerteti a hazai könyvtárosi utánpótlást biztosító, egyedülálló iskola szakmai elkötelezettségét bizonyító innovációkat. Az oktatás és a kutatás nemzetköziesítési törekvéseiből kiindulva felvázolja a neves tudománymetriai rendszerekben mért, ismert és elismert diszciplína, a könyvtár- és információtudomány (Library and Information Science, LIS) turbulens fejlődésében észlelhető globális trendeket, oktatási tendenciákat. Az EU által mért, évente közzétett Digitális Gazdaság és Társadalom Index (Digital Economy and Society Index, DESI) alapján Magyarország digitális kompetencia-szintje jelenleg az uniós átlag alatt van, ennek orvoslására is szolgál az intézetben kidolgozott LIS Skill Center modell. A tervezett központ a multifunkciós könyvtári rendszer és a könyvtári stratégiák eddigieknél is hatékonyabb felsőoktatási támogatását - és nem utolsósorban - a digitális és pénzügyi nyomás hatásait markánsan érzékelő tudomány, hivatás és képzés hazai megerősítését hivatott elősegíteni.

\section{Örökeségünk}

„Könyvtárosi, muzeológusi és geológiai képesitést, továbbá a társadalomtudományi, filozófiai és lélektani tárgykörböl középiskolai tanári képesitést további rendelkezésig csak a budapesti Pázmány Péter tudományegyetemen lehet elnyerni” ${ }^{1}$ - a Vallás- és Közoktatásügyi Minisztérium 1949-ben kiadott rendelete nyomán - hosszú évek küzdelme után ${ }^{2}$ - indulhatott meg az országban a felsőfokú könyvtárosképzés az Eötvös Loránd Tudományegyetem (akkor Pázmány Péter Tudományegyetem) Bölcsészettudományi Karán. A 70 éves évfordulót ünnepeltük 2019. november 26-án és 27-én az immár negyedik alkalommal megtartott Valóságos könyvtár könyvtári valóság (VKKV) konferenciasorozat keretei között. ${ }^{3}$ 
A könyvtár-és információtudomány fejlödése szoros párbuzamba állitható a Könyvtártudományi Tanszék, majd a Könyvtár- és Információtudományi Intézet szakmai törekvéseivel. A „könyvtár, levéltár, rubatár” asszociáció már a múlté. A Google-keresés is csak néhány releváns találatot ad erre a nem éppen hízelgó szókapcsolatra, a találati halmazban inkább a könyvtári és levéltári szabályzatok ruhatárakra vonatkozó passzusai tárulnak elénk - és ez nem véletlen. A nemzetközi tudományos világ ismeri és elismeri a Library and Information Science-t, közkeletű rövidítéssel a LIS-t. Igaz, a Magyar Tudományos Akadémia (MTA) tudományági nómenklatúrájában ${ }^{4}$ nincs regisztrálva a könyvtár- és információtudomány, annak ellenére, hogy a Magyar Tudományos Múvek Tárában (MTMT) alkalmazott, ${ }^{5}$ az Organisation for Economic Co-operation and Development (OECD) kormányközi világszervezethez köthető Frascati-féle tudományosztályozás a társadalomtudományokon belül a média és kommunikáció alá sorolva külön-külön is megjeleníti a könyvtártudományt (Library Science) és az információtudományt (Information Science). A Web of Science (WoS) adatbázisa Information Science \& Library Science elnevezéssel illeti a tudományterületet. ${ }^{7}$ A Scopus-alapú SCImago Journal \& Country Rank (SJR) a Social Science alatt a Library and Information Science kategóriában is közzéteszi Quartilis (Q1, Q2 stb.) rendszerű folyóiratrangsorát, ${ }^{8}$ melynek felhasználásával indiai szakértők kimutatták, hogy 2004 és 2013 között az egész világon nőtt a LIS kutatások volumene. A LIS definiálását, történetének fordulópontjait, alapfogalmainak tisztázását, témaköreinek meghatározását az International Society for Knowledge Organization (ISKO) honlapjáról elérhető enciklopédia adja legteljesebben. ${ }^{10} \mathrm{Az}$ IFLA (International Federation of Library Associations and Institutions) is számos szakfolyóirattal, de friss könyvsorozatokkal is szolgál. ${ }^{11}$ A tudományos irodalmat nem szemléző átlagolvasó (könyvtárhasználó) azonban hazánkban arról tájékozódhat, hogy az információtudomány „az egyik legkeeresettebb tudás a világon, nálunk mégis csak. könyvtár szakon tanulhato”, ami „bármilyen meglepö is, nálunk sokszor a lenézett könyvtártudományra épül." 12

A temérdek impakt faktoros szakfolyóiratot magáénak tudó diszciplína széles körű hazai elfogadtatását is hivatott szolgálni VKKV konferenciasorozatunk, mely a legnagyobb könyvtár- és információtudományi tanácskozás napjaink Magyarországán. Konferenciánk előadásait - immár hagyományosan - lektorált tanulmánykötetben, ${ }^{13}$ jelen esetben a képzés 70 éves történetét feldolgozó bibliográfiával kiegészítve tesszük közzé, ezzel is biztosítva a tudományterület magyar nyelvű szakkönyv utánpótlását. A sorozatot több szakember máris a Könyvtárosok kurrens kézikönyveként emlegeti. ${ }^{14}$

Sok víz lefolyt hét évtized alatt a Dunán, sokat változtak a könyvtárak 1949 óta, s ezáltal más lett a könyvtár- és információtudományi oktatás és kutatás. Az egyes korszakokról tudósítottak ünnepi programjaink: kiállitások, gyűjtemények, portrék és beszélgetések. Kamarakiállításként bemutattuk a későbbiekben közösségi alapon is folyamatosan bővülő virtuális tanszék-, intézet- és képzéstörténeti gyüjteményünket, valamint fényképtárunkat. Egykori tanszékvezetőink, akik már nem ünnepelhetnek velünk - időrendben: Varjas Béla (tanszékvezető: 1949-1951), Harasztby Gyula (1951-1954), Szauder 
A KÖNYVTÁR- ÉS INFORMÁCIÓTUDOMÁNY, VALAMINT A KÖNYVTÁROSKÉPZÉS...

József és Nagy Mikelós (1954-1956), Kovács Máté (1956-1972), Kiss István (1972-1978), Babiczky Béla (1978-1980), Dán Róbert (1980-1986), Fülöp Géza (1986-1994) és Voit Krisztina (1994-1997). Az ő alma materünkhöz kötődő munkásságukat ismertetik az intézetünkben a mai napig megtekinthető portrétablók. Végzett hallgatóinkkal, akik többségével oktatóként is találkozhattunk, pódiumbeszélgetést tartottunk. Borsodi Csaba, karunk történetének legmélyebb ismerője, levéltári kutatásai alapján objektíven feltárta a tanszék alapításának körülményeit. Szabadon elérhetővé tettük Sebestyén Györgynek (tanszékvezető: 1998-2012 ${ }^{15}$ ) a képzés 50 éves történetét feldolgozó monográfiáját. ${ }^{16}$ A múltidézést segítette az egyetemi könyvtárosképzés 50. évfordulóját ünneplő, az ELTE Aula Magnában 1999 októberében zajlott ülésről készült videófelvétel vetítése is, ami az érdeklődők számára folyamatosan elérhető intézeti könyvtárunkban. Konferenciánk a múltat, a jelent és a jövőt szerves egységben tárgyalta, ezért kiemelt szerep jutott benne a szakmai együttmúködő partnereink reflexióinak, majd oktatóink és doktoranduszaink kutatási beszámolóinak. Reményeink szerint mindezzel korántsem teljes, de változatos képet adhattunk könyvtárosképzésünk történetéről, meghatározó eseményeiről, személyiségeiről.

\section{Eredményeink}

Intézetünk nemcsak Magyarország legnagyobb, hanem a teljes felsőoktatási portfóliót gondozó könyvtár- és információtudományi képzőhelye is, ahol működik alapszintű (BA), mesterszintű (MA) és osztatlan tanárképzés (OTAK, rövid ciklusú változatban: RTAK) - mindez nappali és levelező tagozaton egyaránt -, továbbá felvehető az informatikus könyvtáros minor (más BA szak hallgatói számára szakirány vagy specializáció helyetti 50 kredites modul) ${ }^{17}$ és a zenei kultúra alapszakon belül a zenei könyvtáros specializáció. ${ }^{18}$ Ugyanilyen jelentős a kutatási tevékenységünk: hazánkban kizárólag nálunk szerezhető könyvtár- és információtudományból doktori fokozat. ${ }^{19}$ A Könyvtártudományi Doktori Program 1998-as alapítása óta 2020-ban a 46. disszertáció védésére került sor. Sokan nem tudják, hogy 1969-ben nálunk szerzett egyetemi doktori fokozatot Antall József, ${ }^{20}$ Magyarország miniszterelnöke, korábban a Semmelweis Orvostörténeti Múzeum, Könyvtár és Levéltár vezetője.

Országos trend a hallgatói létşámok helyenként drasztikus csökkenése vagy ingadozása a felsőoktatási intézményekben - nincs ez másként a könyvtárosképzésben sem. ${ }^{21}$ A korábbi 11 intézmény helyett ma az Eötvös Loránd Tudományegyetemen (ELTE) kívül csupán a Debreceni Egyetem (DE), az egri Eszterháay Károly Egyetem (EKE), a Pécsi Tudományegyetem (PTE) és a Szegedi Tudományegyetem (SZTE) szervez könyvtárosképzést. ${ }^{22} \mathrm{Az}$ összes képzőhelyen az informatikus könyvtáros alapszak valamennyi tagozatára felvett hallgatók száma 2006-ban 702, 2020-ban 97, a könyvtártudomány mesterszak valamenynyi tagozatára felvett hallgatók száma 2009-ben 149, 2020-ban 25 volt. ${ }^{23}$ A képzés Budapesten stabil. Az országos jelentkezési adatokat áttekintve megállapítható, hogy a BA-s hallgatók közel fele, az MA-sok 60\%-a az ELTE képzését választotta 2020-ban. 
A könyvtárosképzés kizárólag a szakmával való szoros együttmúködésben valósítható meg, csakis velük egy platformra helyezkedve, „,együtt lélegezve” felelhetünk meg a kihívásoknak. Partnerintézményeink bonyolítják a szinte már „duálisnak” számító képzéseink BA-szinten 300 órás, MA-szinten 150 órás szakmai gyakorlatait. Kiváló szakemberek vesznek részt tantárgyfelelősként, oktatóként a munkában, többen közülük szakdolgozatok témakiírói, társtémavezetői, záróvizsgabizottságok külső tagjai, konferenciáink együttmúködő szervezői. A legkorszerúbb ismereteket - úm. könyvtárvezetés, költségvetés-tervezés vagy régi könyves ismeretek - szakmai együttmúködő partereink bevonásával sajátíthatják el hallgatóink.

Nemzetközi szerepvállalásunk egyre meghatározóbb: több mint húsz külföldi partneregyetemmel állunk cserekapcsolatban, megérkeztek első Stipendium Hungaricum ösztöndíjjal támogatott külföldi egyetemi és doktori hallgatóink, vezetjük a CEEPUS (Central European Exchange Programme for University Studies) Library and Information Science in Central Europe hálózatát, részt veszünk a COST (European Cooperation in Science and Technology) Action CA16204 Distant Reading for European Literary History projektben. Barátné Hajdu Ágnes (tanszékvezető: 2013-2020) - első magyarként - a legnagyobb könyvtári világszervezet, az IFL $A$ vezetőtestületének (Governing Board) két cikluson át volt tagja (megbízatása 2019-ben ért véget). A rangos tisztséggel együtt járó óriási kapcsolatrendszernek intézetünk folyamatos haszonélvezője. ${ }^{24}$ Jelen vagyunk elismert nemzetközi szakfolyóiratok (pl. International Journal of Digital Humanities, Webology) szerkesztőbizottságaiban, sorra jelennek meg Q1-es besorolású közleményeink. ${ }^{25}$

Intézetünk szerencsére már nem esik - Varjas Béla szavaival élve - sem az egyetemi, sem a kari vezetés „látóhatárán kívülre.” ${ }^{26}$ Ezúton is szeretnénk megköszönni Borby László rektornak folyamatosan érezhető, kiemelkedő támogatását, mellyel már dékánként is biztosította a digitális környezet sodorvonalában lévő intézetünk szükségszerű fejlesztéseit, ahogy hálásak vagyunk Dezsố Tamás korábbi és Sonkoly Gábor jelenlegi dékánok segítségéért is. Ugyanígy köszönettel tartozunk valamennyi kollégának, továbbá a mindenkori hallgatói képviseletnek, akikkel példaértékű, harmonikus csapatmunkával dolgozunk képzésünk innovációján.

Gereben Ferenc a bolognai átállás kapcsán jegyezte meg: „A felsőoktatásban manapság a nemzetközi egységesités felé mutató, hatalmas méretü szerkezeti átalakitás folyik. De a nagy tektonikus mozgások közö̈t háttérbe szorulnak olyan, egyáltalán nem lényegtelen kérdések, hogy a jövö diplomásai emelt szintü (?) szaktechnikusok legyenek-e vagy értelmiségiek??"27 Természetesen az utóbbi mellett tettük le voksunkat. Tagsággal bírunk a Magyar Rektori Konferencia (MRK) Társadalomtudományi Bizottságában, ami jelentősen segíti az információszerzést és érdekeink érvényesítését. Talán soha nem volt ilyen szoros a könyvtárosképző intézmények közötti kapcsolat sem. Öt esztendővel ezelőtt, kezdeményezésünkre jött létre a Könyvtárés Információtudományi Képzésele. Kollégiuma (KIKK), ahol nemcsak a társtanszékek képviselői, hanem a munkavállalók és munkaadók reprezentatív szakmai szervezetei - a Magyar Könyvtárosok. Egyesülete (MKE), az Informatikai és Könyvtári Szövetség (IKSZ), az Egyetemi 
A KÖNYVTÁR- ÉS INFORMÁCIÓTUDOMÁNY, VALAMINT A KÖNYVTÁROSKÉPZÉS...

Könyvtárigazgatók Kollégiuma (EKK) - mellett a Hallgatói Önkormányzatok Országos Konferenciájának (HÖOK) delegáltja közösen fogalmaz meg javaslatokat kulcskérdésekben és képviseli a képzés érdekeit, olykor a különböző álláspontoknak a szakmát előre vivő ütköztetése árán. Így - konszenzussal - született meg az informatikus könyvtáros BA és a könyvtártudomány MA oktatását ma is meghatározó képzési és kimeneti követelmények, azaz a KKK. ${ }^{28}$ „Kevés ember eléggé bölcs ahhoz, hogy a mérgezett dicséretnél többre becsülje a hasznos kritikát' ${ }^{29}$ - valljuk, hogy François de La Rochefoucauld gondolatának megszívlelésével lehet prosperáló könyvtár- és információtudományi képzést szervezni.

\section{Útkereséseink}

Hallgatóink már az első egyetemi előadásokon megtanulják, hogy a könyvtári rendszer nem önmagáért és önmagában, hanem bálózatként, archivátorként és szolgáltatóként, a gazdasági, társadalmi, technológiai (és politikai) környezeti tényezők befolyása alatt, a nemzetközi és hazai trendek indukálta felhasználói igények szorításában létezik. A könyvtár klasszikus definíciója - azaz könyvtári dokumentumok (információhordozók) tervszerűen gyarapított (vagyis alakított, hiszen az apasztásról sem szabad elfelejtkezni) rendezett és feltárt, megőrzésre és használatra szánt gyűjteménye -, amit jelen sorok írója Ferençyy Endrénétől tanulhatott meg, a bibliotékák klasszikus (mai szemmel alapvető) funkciórendszerét vázolja. 2020-ban a könyvtár multifunkciós, ahol a dokumentumokról az információk szolgáltatására helyeződik a hangsúly, ahol a kulturális örökség megőrzése mellett ugyanolyan fontos a közösségi térként és a szociálisan érzékeny intézményként való működés, de nem megkerülhetők további kiegészítő (pl. pénzügyi edukációs) vállalások sem. Kultúrafogyasztási verseny zajlik, az emberek élményekre vágynak, nem elegendő a minőségi szolgáltatás, korszerű környezetre, modern és fenntartható könyvtári helyszínekre, épületekre van szükség. A szeparált intézményi törekvések nem kedveznek a felsorolt célok megvalósításának: azok csak integráltan, közgyűjteményi (könyvtár, levéltár, múzeum) összefogással, a majdan felmerülő igényekre proaktivan reagálva képzelhetók el.

A könyvtári gyakorlat nem létezhet támogató tudományos és oktatási háttér nélkül. A könyvtár- és információtudományi szakirodalom rövid áttekintéséből is leszűrhető, hogy mind a diszciplína, mind a képzés előtt számos útelágazás áll. A probléma nem újkeletű: Thomas Kubn A tudományos forradalmak szerkęete címú műve ${ }^{30}$ óta köztudott, hogy a tudományos fejlődés nem csupán az ismeretek elsajátításából áll, természetes velejárója a dilemmák - olykor vehemensebb lefolyású, nem feltétlenül egymásra épülő és rendezett - felszínre hozása, melynek eredménye a paradigmaváltás. Nem kezdünk tudományfilozófiai fejtegetésekbe, csupán néhány meghatározó axiómát emelünk ki napjaink tudományos diskurzusából. 
Az elmúlt években vendégelőadóként intézetünkben rendszeresen megfordult Ragnar Andreas Audunson a patchworkhöz hasonlította az utóbbi évtizedekben Európában jórészt elszigetelten fejlődött könyvtár- és információtudományt, holott annak multidiszciplinaritásához nem férhet kétség, és amelyet nem lehet kizárólag bölcsészettudományi, társadalomtudományi, műszaki vagy természettudományi, esetleg informatikai besorolással illetni, továbbá nem lehet tisztán elméleti, tudományos megközelítéssel művelni. A LIS szorosan kapcsolódik egy szakmai-gyakorlati területhez, ennek a praktikumnak a fejlesztése a végső célja és létjogosultsága. ${ }^{31}$ A Michael Denisig ${ }^{32}$ és Martin Schrettingerig ${ }^{33}$ visszavezethető LIS-történet a könyvtártudomány és az informatika kapcsolatában gyökerezik. ${ }^{34}$ Fredrick Kiwuwa Lugya kifejti, hogy a könyvtár- és információtudományban két terület áll erőteljes interdiszciplináris kapcsolatban, mely az idők folyamán nőtt fel önálló, folyamatosan fejlődő, dichotómikus tudománnyá. Történelmileg az információ episztemológiai koncepciója a könyvtárosság átalakulásához vezetett. A megnevezés pedig a dokumentáció, a könyvtártudomány, az informatikai/információs tanulmányok, a könyvtári és dokumentációs tanulmányok, a könyvtár- és információtudomány, az információs iskola (iSchools ${ }^{35}$ ) íven halad, amit leképeznek az egyetemi intézetek, tanszékek nevei is. A Library Science Abstracts referálólap (ma ProQuest adatbázis ${ }^{36}$ ) 1969-tól már Library and Information Science Abstracts címen jelenik meg. ${ }^{37}$ A LIS tehát megkérdőjelezhetetlenül önálló diszciplína, identitásának erősítése azonban elkerülhetetlen. ${ }^{38}$ Kuhnra visszautalva a LIS több, mint megjegyzendő tények vagy elsajátítandó technikák gyújteménye, saját érvelési hagyománya van, erőteljes társadalmi relevanciával bír, más tudományterületekkel diskurzusokat, tudáscserét folytatva fejlődő és változó (amely akár módosítja vagy elveti korábbi elfogadott következtetéseit, ha teljesebb, megbízhatóbb bizonyítékok merülnek fel), diszkurzív képződmény.

A már idézett Audunson megállapítja, hogy a könyvtár és a könyvtáros szakma jelentős nyomás alatt dolgozilk, hiszen a digitális világban elterjedt általános nézet: nincs szükség információközvetítőkre, az információkhoz mindenki hozzáfér az internet segítségével. A skandináv könyvtárakban is egyre több nem szakirányú végzettséggel rendelkező kollégát alkalmaznak. Az információk előállítása, feltárása, rendszerezése, visszakereshetőségének biztosítása, közzététele, tárolása az átlagember számára sokszor láthatatlan tevékenység, csak az „ingyenes” szolgáltatással találkozik a felhasználó. (Ingyenes szolgáltatás megítélésünk szerint nem létezik, csak - látszólag - az igénybe vevő részérôl, hiszen a szolgáltatás biztosításáért valamely szervezet - vagy éppen az adózó polgárok pénzéből az állam - mindig fizet.) Nem beszélve az információk relevanciájáról és megbízhatóságáról. ${ }^{39}$ A könyvtár demokratikus intézmény, közösségi találkozóhelyként, valamint a nyilvános vita és beszélgetés színtereként kap fokozott hangsúlyt, a könyvtárak egyre inkább eltávolodnak a fizikai gyüjtemény kötöttségeitöl. Az oktatási programokhoz igazodó szakmai gyakorlatok elsődleges célja elsősorban a társadalmi felelősségre, és nem a fizikai gyűjtésre összpontosítani. Ennek a szabadságnak a kihasználása fenyegetést és kihívást is jelenthet, új távlatokat nyithat a LIS számára: 
a Gutenberg-galaxis nem hozta el a veleszületett írástudást és olvasást, a digitális forradalom pedig automatikusan nem jár együtt az információs múveltséggel. A legújabb kutatások azt mutatják, hogy még a digitális bennszülötteknél is mítosz az információs készségek birtoklása. Pusztán azért, mert soha nem ismertek a jelenlegin kívül más világot, nem lehet még következtetni sem arra, milyen lenne az információkeresési képességük a ma rendelkezésükre álló eszközök, applikációk, chatek stb. nélkül. A jövőben olyan könyvtárosokra lesz szükségünk, akik kulturális és oktatási háttérrel rendelkeznek, képesek navigálni a komplex információs rendszerek világában. A könyvtárosok kisebb része fog közvetlenül például dokumentumokat feldolgozni, azonban a klasszikus tantárgyakban oktatott és a történeti vonatkozású ismeretekre továbbra is szükség van ahhoz, hogy a leendő szakemberek megértsék a digitális kor kihívásait és adekvát megoldásokkal szolgáljanak. Az oktatásnak továbbra is ezekre a hagyományos LIS-készségekre kell építenie. ${ }^{40}$

A szakmai körökben jól ismert IFLA trendek és azok aktualizálásai ${ }^{41}$ mellett az Amerikai Könyvtárosegyesület (American Library Association, ALA) State of America's Libraries Report 2020 áprilisában közzétett szakértői anyagára ${ }^{42}$ irányítjuk rá a figyelmet. ${ }^{43}$ Az ALA Jövő Könyvtára Központja (Center for the Future of Libraries) meghatározása szerint a következő globális trendek hatnak majd a könyvtárak szolgáltatásaira, egyúttal a képzésre is:

- fenntartható közlekedés (mobility and transportation);

- együttes elhelyezés, helymegosztás (colocation);

- hozzáférés megkönnyítése (making access easier);

- mesterséges intelligencia (artificial intelligence).

Ehhez a felsoroláshoz társulnak még a 2020-ban kiteljesedő COVID-19 koronavírus világjárvány napjainkban még nem meghatározható, csak sejthető hatásai.

Az oktatás egyik szintje sem létezhet a technológiától függetlenül. A multimédiás eszközök már viszonylag elterjedtek, de a motivációt fokozzák az interaktivitást és a szimulációt középpontba helyező, feltörekvőben lévő alkalmazások is. A játékalapú online társas tanulás széles alkalmazásáról még nem beszélhetünk, ahogy a tanulásanalitika, a mesterséges intelligencia vagy a virtuális valóság is a jövő megoldásai közé tartozik. ${ }^{44}$ A könyvtárosképzés a szakmai és az oktatási környezet miatt sincs könnyú helyzetben, útkeresése világszinten tetten érhető. Az IFLA külön munkacsoportot (Building Strong Library and Information Science Education, BSLISE Working Group) is felállított, melynek első eredményeképpen helyzetelemzés született. ${ }^{45}$ A szakértői anyag leírja, hogy nemcsak nemzetközi szinten, hanem az ALA-akkreditáció ${ }^{46}$ ellenére az Amerikai Egyesült Államokban sem egységes a képzés struktúrája és tartalma, azaz a „virágozzék minden virág” elv érvényesül. A kutatás reprezentativitása vitatható, azonban megállapításaival egyet lehet érteni. A diszciplína napról napra változik: a képzés globális szemléletű újragondolása nem várhat évekig, ${ }^{47}$ a kompetenciakövetelmények aktualizálása ${ }^{48}$ pedig félévrôl félévre elvégzendő oktatói munka. ${ }^{49}$ A képzésnek és a gyakorlatnak - a szinte mindenütt tetten érhető feszültségek ellenére - törekednie kell a tandemszerü együttmüködésre. ${ }^{50}$ 
A gyors változások miatt a friss oklevél csak kiindulópont lehet, az egyetemen megszerzett alapokra kell építenie a gyakorlatnak, hiszen a képzési ciklus végére a technológiai ismeretek akár már el is avulhatnak, szemben például a kommunikációs készségek fejlesztésével. Az egyes könyvtártípusoknál más és más kompetenciaelvárások merülnek fel, ${ }^{51}$ ezek kezelése nehézségekbe ütközik a tantervek kialakításánál. Egyre hangsúlyosabban jelentkezik a projektmenedzsment, a csoportmunkára történő felkészítés, a felhasználóközpontú tervezối gondolkodás (design thinking).

A LIS-diploma jól konvertálható tudást ad, a sqakma presz̧tízse és bérezése azonban nem könyvtári munkaadók és nem könyvtári feladatok felé kényszeríti a végzetteket. ${ }^{52}$ Az igazsághoz az is hozzátartozik, hogy sokan más karriercél miatt lépnek a képzésbe. Nemzetközi hatású, a pályaelhagyást mérséklő, a sztereotípiákat eloszlató marketingkampány nélkül nehéz helyzetbe kerül az intézményrendszer, kiürül elsősorban a mester- és a doktori képzés. ${ }^{53}$ Manapság az állások már nem egy életre szólnak, és még a könyvtárakban is újabb és újabb munkaköri elnevezések (pl. discovery librarian) bukkannak fel. ${ }^{54}$ Egyre erősödik a közgyújteményi nem formális oktatási funkció, például a pénzügyi tudatosság fejlesztése. ${ }^{55}$ Ennek hatására a felsőoktatásnak is fel kell vállalnia a továbbképzésekeet biztosító tanfolyami kereteket, ${ }^{56}$ a külső partnerekkel való minden eddiginél intenzívebb kapcsolatépítést, a mentori rendszerek kialakítását. ${ }^{57}$ Mindezekből kitűnik, hogy a LIS az átmenet időszakát éli: a könyvtári intézményrendszerhez való szoros kötődése miatt az ott kialakult negatív hatások a képzésben és az atipikus elhelyezkedésben is tetten érhetők. A hallgatókat az egész pályára képesítő dinamizmusra, az összetartó identitásra és érdekeképviseletre szükséges felvértezni. ${ }^{58} \mathrm{Az}$ egyetemek - kényszerűségbôl - nem tehetnek mást, mint felkészítenek a könyvtáron kívüli munkavégzésre is, ötkomponensû ún. transzferábilis kompetenciafejlesztést végezve:

1. az ügyfélszolgálatra;

2. a szükségletek felismerésének képességére;

3. az információkeresésre és az adatbázishasználatra;

4. az információforrások hitelességének megállapítására;

5. valamint a munkahelyi környezetre való felkészültség priorizálásával. ${ }^{59}$

A nemzetközi kutatások világosan megerősítik a diszciplína és a szak sajátos helyzetét, a kivülállók pontatlan megitélését (ld. pl. a könyvtáros a könyvekkel vagy az olvasással foglalkozik), ami ahhoz vezet, hogy csökken a pályaválasztási hajlandóság, a pályán maradás és a hivatástudat. A LIS-nek - társadalmi és gazdasági jelentőségénél fogva - a jelenleginél sokkal meghatározóbb pozícióban lenne a helye. ${ }^{60} \mathrm{~A}$ probléma nem újkeletú. Ide kívánkoznak Vértesy Miklós 1987-ben írt - a magyarországi szakma kezdeti érdekérvényesítéséről szóló - gondolatai: „Sokan magát a könyvtárosságot tájékozatlanságból amolyan nem sok. hasznot hajtó tevékenységnek, mellék.foglalkozásnak. tartották. Még a könyvtárosok közül is nem kevesen csak ugródeszkának tekintették munkahelyüket más, nagyobb jövedelemmel kecsegtetö állásokera. [...] A felettesei által könyvtárkezelönek megtett tanitó, Csupay Lajos panaszát említem 
A KÖNYVTÁR- ÉS INFORMÁCIÓTUDOMÁNY, VALAMINT A KÖNYVTÁROSKÉPZÉS...

a harmincas évek elejétöl: «a marhalevélkezelö, a mázsakez̨elo", húsvizsgáló dijazást kap, a toronyóra felbúrója [is], csak a könyvtáros nem kap a munkájáért semmit.»" 61

A Vértesy Mikéós által leírtaknál a helyzet ma ennél valamivel jobb. A Diplomás Pályakövetési Rendszer (DPR) adatai szerint azonban a BA és MA diplomával frissen végzettek kezdőfizetése közötti bérkülönbség csekély: a BA diplomásoké átlag $232000 \mathrm{Ft}$, az MA diplomával rendelkezőké pedig $245000 \mathrm{Ft}^{62}$ Nem lehet tehát csodálkozni a mesterszakot övező kisebb érdeklődésen (és a nappalival szemben a levelező tagozat dominanciáján). A vezetői utánpótlásnevelés és a doktori képzésre történő felkészítés deklaráltan ennek a szintnek a feladata. Itt kell említést tenni arról, hogy a Központi Statisztikai Hivatal (KSH) három évvel ezelőtti felmérése szerint a könyvárosok presztízse többek között a profi bokszoló, az őstermelő, a rockzenész utáni helyen áll, majd őket követik a víz- és gázszerelők, a bölcsődei gondozók és a balett-táncosok. ${ }^{63}$

Mindezek ellenére tud jelentős sikereket felmutatni képzésünk, mind kvantitatív, mind kvalitatív szempontból. Képzeljük csak el mi lenne, ha a kezdőfizetés a versenyszféra bérszínvonalát akár csak közelítené, és ha a szakmai presztízsünk csekély mértékben is javulna? Egy sor sikeres könyvtári projektet és valóban egységes könyvtári rendszert és egységben gondolkodó könyvtárosokat tudnánk felmutatni a jelenlegi, szigetszerú jó gyakorlatok mellett?

Bármennyire is azon dolgozunk, hogy Magyarország legnagyobb kulturális intézményhálózatának, a könyvtári rendszernek biztosítsunk munkaerőutánpótlást, rajtunk kívül álló okokból végzettjeink jelentős része - sajnos távozik a pályáról. Így a képzés nemzetgazdasági szinten megtérül, még akkor is, ha a mi végzettünk ma már nem könyvtárosként helyezkedik el, hanem valami más, jobban fizetett szakmában találja meg számítását. A DPR adatok szerint a piaci szektor szívesen foglalkoztatja a könyvtárosként diplomázottakat (a BA-t végzetteknél 45,16-45,16\% a közszférában, illetve a versenyszférában, 6,45\% az egyéb és 3,23\% a non-profit szektorban elhelyezkedôk aránya ${ }^{64}$ míg az MA-t végzettek 71,43\%-a a közszférában, 22,86\%-a a versenyszférában és 5,71\%-a a non-profit szektorban helyezkedett $\mathrm{el}^{65}$ ), ennek egyik oka hallgatóink digitális kompetenciáinak átlagon felüli színvonala. ${ }^{66}$ A DPR azt is bizonyítja, hogy igen alacsony a végzettek között az álláskereső́k aránya (BA diplomával 7\%, MA-val csupán 4\%). Képzésünk tehát egyértelműen versenyképes.

Eltérünk az átlagtól, hiszen más bölcsész- és társadalomtudományi besorolású szakoktól eltérően számítógépes laborokra, szoftverekre van szükségünk az oktatásban. Az infokommunikáció rohamos változásai miatt a nemzetközi versenyképességhez elengedhetetlen a legkorszerúbb informatikai berendezések és technológiák alkalmazása, azok fenntartása és múködtetése, a hazai és nemzetközi külső szakértők időszakos bevonása, a tananyagok állandó korszerúsítése, a hazai és nemzetközi szakmai együttmúködések még erőteljesebb fellendítése, a szakmai gyakorlatok rendszerének újradefiniálása, összhangban a külföldi trendekkel és a hazai könyvtári stratégiai törekvésekkel - ezeket a feladatokat hivatott ellátni a tervezett LIS Skill Center az ELTE BTK Könyvtár- és 
Információtudományi Intézetében. A digitális kornak megfelelő könyvtáros és információs szakemberképzés (amely nemcsak a szakkönyvtári és a felsőoktatási könyvtári szférát, de a tudományos információszolgáltató intézményeket és innovációs központokat, vállalkozásfejlesztési szervezeteket is ellátja munkaeróvel) hazai oktató-, kutatóés módszertani központjának forrásbővítése Magyarország szakterületi lemaradásának megakadályozása, többek között az Európai Bizottság által készített Digitális Gazdaság és Társadalom Index (Digital Economy and Society Index, DESI) ${ }^{67}$ értékének javítása, vagyis a magyar lakosság - 2020-ban az uniós átlag alatti - digitális kompetenciaszintjének javítása érdekében elengedhetetlen. Ehhez példa nélküli keretet nyújt a tudományegyetemi szervezetben, önálló intézetként, két tanszékkel (Könyvtártudományi Tanszék, Információtudományi Tanszék), szakkönyvtári háttérrel múködő oktató-kutatóhely, az ELTE BTK Könyvtár- és Információtudományi Intézete.

\section{Hasznosságunk}

Közhelynek látszik, de attól még igaz - és a szakmai trendek tárgyalása után is rá kell világítanunk -, hogy napjainkban csak a változás állandó: talán nincs még egy olyan, a környezeti változásokhoz rugalmasan alkalmazkodni kényszerülő bölcsész- és társadalomtudományi szakma, mint a miénk. A naponta újabb és újabb informatikai megoldások világában az információs rendszerek múködtetéséért felelős szakemberekként nincs könnyű helyzetünk. Ráadásul nekünk minden könyvtártípus egyaránt fontos, a multifunkciós könyvtári rendszer nemcsak tudósokat kiszolgáló szakkönyvtárosokból vagy tanulni vágyó diákokat fogadó felsőoktatási könyvtárakból áll, hanem olyan szakemberekből, akik a nap huszonnégy órájában múködtetik a közkönyvtári hálózatot, a „város nappaliját", a fővárostól egészen a mélyszegénységben élők lakta településen át, esetenként mozgókönyvtári ellátással, és nem túlzás: földön, vízen és a levegőben. ${ }^{68}$ Horváth Tibor - Morris B. Line gondolatait is felhasználva - így érvelt 1999-ben: „A könyvtárak dolga nem más, mint managing information resources for people. Világos: nincs szó dokumentumról, könyvröl, olvasóról, felhasználóról, hanem információs forrásokeól és az emberekröl. Tehát mindenkiröl és minden forrásról. Még egyszuer: bármely információt el kell juttatni bárki számára bárhová. De ez. már rendszerprobléma. Nincs autonóm könyvtár, elhanyagolhatók a könyvtárfajták. különbségei. Vagy másként alakulnak a különbségek. A modern ellátásban megszünik az egyenetlenség országok, régiók, települések. között. Ebben áll a könyvtárak egysége, amelyet eddig csak. hitvallásként hangoztattunk mindaddig, amíg a valóság ki nem józanitott bennünket. Szeretnünk is kell a könyvtárakat. Ebböl ered a hivatástudat." ${ }^{\prime 9}$

A világ 2020-ra sem vált könyvtárrá a tömeges digitalizálás hatására, ahogy nem lett mindenki könyvtáros attól, hogy az információk nem kötődnek intézmények kézzelfogható gyűjteményeihez. Releváns és megbízható forrásokat szolgáltató információközvetítőkre, fenntartható, multifunkciós, közösségi és oktatási terekre - vagyis könyvtárakra továbbra is szükség mutatkozik. Társadalmi hasz̧nosságunk bizonyítható és akár számsze- 
rűsíthető is, ${ }^{70}$ de folyamatosan meg kell dolgoznunk érte. Churchill szerint: „a nagyság ára a felelösség." "1 A mindenütt jelen lévő könyvtár és könyvtáros társadalmi felelössége, ahogy az elmúlt évtizedekben, évszázadokban, évezredekben, úgy az elkövetkezendőkben is sziklaszilárdan fennáll. A képzőhelyek oktatóinak, hallgatóinak és a szakmában ténykedő könyvtárosoknak vállvetve kell képviselniük a társadalom tagjai, de különösen az eljövendő generációk iránti felelősséget.

Késæült a Bolyai János Kutatási Ösztöndíj támogatásával.

\section{Jegyzetek és irodalom}

1. A vallás- és közoktatásügyi miniszter 600/1949. V.K.M. számú rendelete a bölcsészettudományi és természettudományi karok tanulmányi- és vizsgarendjének szabályozása tárgyában. 19. \ (3) Megjelent: Köznevelés, 5. évf. 3. sz. (1949. február 1.) 12. p. Forrás: https:// adtplus.arcanum.hu/hu/view/Kozneveles_1949_rendeletek/?pg=12\&layout=s [2020. szeptember 20.]

2. CZÖVEK Zoltán: Az egyetemi könyvtárosképzés megindulása Magyarországon. = Képzés és Gyakorlat, 8. évf. 3/4. sz. 2010. 21-42. p. Forrás: http://trainingandpractice.hu/?q=hu/ kepzes_es_gyakorlat/content/1486053293 [2020. szeptember 20.]

3. KISZL Péter - BODA Gáborné KÖNTÖS Nelli (szerk.): Valóságos könyvtár - könyvtári valóság IV. Konferenciaprogram az előadások tartalmi összefoglalóival. Budapest, ELTE BTK Könyvtár- és Információtudományi Intézet, 2019. Forrás: http://hdl.handle. net/10831/44574 [2020. szeptember 20.] és FODOR János: Konferencia és ünnep. Valóságos könyvtár - könyvtári valóság IV. konferencia az Eötvös Loránd Tudományegyetemen. = Könyvtári Figyelő, 30. (66.) évf. 1. sz. 2020. 41-53. p. Forrás: http://epa.oszk. hu/00100/00143/00359/pdf/EPA00143_konyvtari_figyelo_2020_01_041-053.pdf [2020. szeptember 20.]

4. Ki hová tartozik? Elkészült az új tudományági besorolás. MTA. 2016. szeptember 12. Forrás: https://mta.hu/mta_hirei/ki-hova-tartozik-elkeszult-az-uj-tudomanyagi-besorolas106818 [2020. szeptember 20.] Tudományági nómenklatúra. MTA. 2017. október 17. Forrás: https://mta.hu/doktori-tanacs/tudomanyagi-nomenklatura-106809 [2020. szeptember 20.]

5. Tájékoztató a Frascati-rendszerü tudomány-rendszertani osztályozás bevezetéséről a Magyar Tudományos Múvek Tárában. MTMT. Forrás: https://www.mtmt.hu/hirek/tajekoztatofrascati-rendszeru-tudomany-rendszertani-osztalyozas-bevezeteserol-magyar [2020. szeptember 20.]

6. Frascati Manual. OECD. Forrás: http://www.oecd.org/sti/inno/frascati-manual.htm [2020. szeptember 20.]

7. „Information Science \& Library Science covers resources on a wide variety of topics, including bibliographic studies, cataloguing, categorization, database construction and main- 


\section{KISZL PÉTER}

tenance, electronic libraries, information ethics, information processing and management, interlending, preservation, scientometrics, serials librarianship, and special libraries." Master Journal List. Scope Notes. Social Science Citation Index (SSCI). Web of Science (WoS). Forrás: http://mjl.clarivate.com/scope/scope_ssci/\#WU [2020. szeptember 20.]

8. Library and Information Science. Journal Rankings. SJR - Scimago Journal \& Country Rank. Forrás: https://www.scimagojr.com/journalrank.php?category=3309 [2020. szeptember 20.]

9. PANDITA, Ramesh - SINGH, Shivendra: Research growth in lis during last decade: a study. = Library Review, Vol. 64. No. 8/9. 2015. 514-532. p. Forrás: https://doi. org/10.1108/LR-04-2015-0037 [2020. szeptember 20.]

10. HJØRLAND, Birger: Library and information science (LIS). = Hjørland, Birger - Gnoli, Claudio (ed.): ISKO Encyclopedia of Knowledge Organization. Forrás: http://www.isko. org/cyclo/lis [2020. szeptember 20.]

11. IFLA Publications. Forrás: https://www.ifla.org/ifla-publications [2020. szeptember 20.]

12. MOLNÁR Barbara: Digitális nyomolvasó kerestetik. = HVG, 38. évf. 11. (1915.) sz. (2016. március 12.) 54. p.

13. Korábbi köteteink: KISZL Péter - BODA Gáborné KÖNTÖS Nelli (szerk.): Valóságos könyvtár - könyvtári valóság. Könyvtár- és információtudományi tanulmányok 2016. Budapest, ELTE BTK Könyvtár- és Információtudományi Intézet, 2017. Forrás: https:/ / edit. elte.hu/xmlui/handle/10831/34590 [2020. szeptember 20.]; KISZL Péter - CSÍK Tibor (szerk.): Valóságos könyvtár - könyvtári valóság. Könyvtár- és információtudományi tanulmányok 2018. Budapest, ELTE BTK Könyvtár- és Információtudományi Intézet, 2018. Forrás: https://doi.org/10.21862/vkkv2018 [2020. szeptember 20.]

14. HORVÁTH Tibor - PAPP István (szerk.): Könyvtárosok kézikönyve. 1-5. köt. Budapest, Osiris Kiadó, 1999-2003. (Osiris kézikönyvek) 1. köt., Alapvetés, 1999.; 2. köt., Feltárás és visszakeresés, 2003.; 3. köt., A könyvtárak rendszere, 2001.; 4. köt., Határterületek, 2002; 5. köt., Segédletek, 2003.

15. 1997-1998 között - átmeneti jelleggel - Bak Borbála (Történeti Intézet) vezette a tanszéket.

16. SEBESTYÉN György: Az egyetemi könyvtárosképzés ötven éve. Budapest, ELTE Eötvös Kiadó, 2001.

17. KISZL Péter: A könyvtár- és információtudományi képzés ökológiája. = Könyvtári Figyelő, 30. évf. 1. sz. 2020. 9-40. p. Forrás: https:/ /epa.oszk.hu/00100/00143/00359/pdf/ EPA00143_konyvtari_figyelo_2020_01_009-040.pdf [2020. szeptember 20.]

18. KISZL Péter - NÉMETH Katalin: Diszciplínák metszéspontjában: zenei könyvtárosok képzése az Eötvös Loránd Tudományegyetemen. = Parlando, 62. évf. 3. sz. 2020. Forrás: http://www.parlando.hu/2020/2020-3/Kiszl_Peter-Nemeth_Katalin.pdf [2020. szeptember 20.]

19. KISZL Péter: Kutatás és innováció: kompetenciafejlesztés a könyvtár- és információtudományi doktori képzésben. = Barátné Hajdu Ágnes (szerk.): Szakmai ismeretek és készségek - átalakuló hivatás. Válogatott könyvtártudományi tanulmányok. Budapest, Magyar Könyvtárosok Egyesülete, 2020. 163-178. p. Forrás: https://doi.org/10.46280/ KOMPKONF.2020.Kiszl [2020. szeptember 20.]

20. ANTALL József: Eötvös József és a Politikai Hetilap 1865-1866. Budapest, ELTE BTK, 1969. 
A KÖNYVTÁR- ÉS INFORMÁCIÓTUDOMÁNY, VALAMINT A KÖNYVTÁROSKÉPZÉS...

21. Vö. „A Bizottság egyúttal felhívja a jogalkotók figyelmét olyan anomáliákra, amelyek a felsőoktatási szférán kívüli, ám annak működését közvetetten mégis érintő jogalkotás eredményez. Ilyen pl. a közalkalmazottak jogállásáról szóló 1992. évi XXXIII. törvény végrehajtásáról a művészeti, a közművelődési és a közgyűjteményi területen foglalkoztatott közalkalmazottak jogviszonyával összefüggő egyes kérdések rendezésére született 150/1992. (XI. 20.) Korm. rendelet 6/B. \-a, ami OKJ szerinti segédkönyvtárosi szakképesítéssel is lehetôvé teszi könyvtárvezetői beosztások betöltését nem szakirányú felsőfokú végzettséggel és szakképesítéssel rendelkező személyek számára. A bizottság véleménye szerint az ilyen, a felsőoktatás területén kívül eső jogalkotás leértékeli a felsőoktatásban szerezhető szakmai végzettségeket és szakképesítéseket, amitől a szakmai követelmények biztosítása érdekében tartózkodni kell” - részlet a Bologna-revízió kapcsán a Magyar Rektori Konferencia Társadalomtudományi Bizottságának (MRK TTB) 2019. november 4-én megfogalmazott javaslatából.

22. A 2020/2021-es tanévre a Nyíregyházi Egyetem (NYE) is meghirdette az alapszakot, de kellő jelentkező hiányában nem indult el.

23. A Felvi portál alapján készített felvételi statisztikákat ld.: ELTE-LIS felvételi statisztika. Forrás: http:// elte-lis.blogspot.com/p/elte-lis-felveteli-statisztika.html [2020. szeptember 20.]

24. KISZL Péter: Könyvtárdiplomácia - tudomány- és szakmapolitika a nemzetközi könyvtáriinformációs szervezetekben. In: Kiszl Péter - Németh Katalin (szerk.): Információközvetítés és közösségépítés - multifunkciós könyvtári hálózatok. Budapest, ELTE BTK Könyvtár- és Információtudományi Intézet, 2020. 9-30. p. Forrás: https://doi.org/10.21862/ infkoz.9 [2020. szeptember 20.]

25. Doktori programunk nemzetközi elismertségét jelzik az oktatói és doktoranduszi múhelymunkában készült, Q1-es besorolású publikációk. 2020-ban: NAGY Andor - KISZL Péter: Personal digital legacy preservation by libraries. $=$ Journal of Librarianship and Information Science. Forrás: https://doi.org/10.1177\%2F0961000620948574 [2020. szeptember 20.]; WINKLER Bea - KISZL Péter: Academic libraries as the flagships of publishing trends in LIS: a complex analysis of rankings, citations and topics of research. = The Journal of Academic Librarianship, Vol. 46. No. 5. 2020. Forrás: https://doi.org/10.1016/j. acalib.2020.102223 [2020. szeptember 20.] és KÁROLY Krisztina - WINKLER Bea KISZL Péter: "Across" 20 years: A bibliometric analysis of the journal's publication output between 2000 and 2020. = Across Languages and Cultures, Vol. 21. No. 2. 2020. 145-168. p. Forrás: https://doi.org/10.1556/084.2020.00010 [2020. szeptember 20.]

26. «Varjas Béla hozzászólásában kitért arra, hogy a könyvtár szak a Bölcsészettudományi Kar „látóhatárán ... kívül esik.”» Idézi: POGÁNYNÉ RÓZSA Gabriella: A könyvtár szakos képzés megszervezése a hazai felsőoktatásban. = Könyv és Nevelés, 18. évf. 1. sz. 2016. 18. p. Forrás: https://folyoiratok.oh.gov.hu/sites/default/files/journals/konyv_es_ neveles_2016-1.pdf [2020. szeptember 20.] Forrás: Jegyzőkönyv az Eötvös Loránd Tudományegyetem Bölcsészettudományi karának 1951. évi júl. 6-án ... tartott ... tanácsüléséről. 8. p. ELTE Levéltára, Fond 8/a.

27. GEREBEN Ferenc: Olvasás felsőfokon? Benyomások az egyetemisták olvasáskultúrájáról. = Könyv, Könyvtár, Könyvtáros, 16. évf. 1. sz. 2007. 26. p. Forrás: http://www.epa.oszk. hu/01300/01367/00131/94.htm [2020. szeptember 20.] 
28. KISZL Péter: Újratervezés a könyvtárosképzésben. = Tudományos és Műszaki Tájékoztatás, 62. évf. 11/12. sz. 2015. 399-414. p. Forrás: https://tmt.omikk.bme.hu/tmt/article/ view/605 [2020. szeptember 20.] és 18/2016. (VIII. 5.) EMMI rendelet a felsőoktatási szakképzések, az alap- és mesterképzések képzési és kimeneti követelményeiről, valamint a tanári felkészítés közös követelményeiről és az egyes tanárszakok képzési és kimeneti követelményeiről szóló 8/2013. (I. 30.) EMMI rendelet módosításáról. Forrás: http:/ / njt.hu/ cgi_bin/njt_doc.cgi?docid=196922.364718 [2020. szeptember 20.]

29. LA ROCHEFOUCAULD, François de: Maximák. Budapest, Helikon Kiadó, 1990. 42. p.

30. KUHN, Thomas S.: A tudományos forradalmak szerkezete. Az utószót írta Fehér Márta. Ford. Bíró Dániel. Budapest, Gondolat, 1984. (Társadalomtudományi könyvtár)

31. AUDUNSON, Ragnar A.: Library and information science education - discipline profession, vocation? = Journal of Education for Library and Information Science, Vol. 48. No. 2. 2007. 94-107. p. Forrás: https://www.jstor.org/stable/40323811 [2020. szeptember 20.]

32. DENIS, Michael: Aufsehers der garell. Biblioth. am k.k. Theres. und Lehrers an der k.k. sav. Akad. Einleitung in die Bücherkunde. Wien, Trattner, 1777. 4 N.libr. 13-1/2. Forrás: http://mdz-nbn-resolving.de/urn:nbn:de:bvb:12-bsb10528369-3 [2020. szeptember 20.]

33. SCHRETTINGER, Martin: Versuch eines vollständigen Lehrbuches der Bibliothek-Wissenschaft oder Anleitung zur vollkommenen Geschäftsführung eines Bibliothekärs: in wissenschäftlicher Form abgefasst. München, 1829. Rar. 722 a-1. Forrás: http://mdz-nbn-resolving.de/urn:nbn:de:bvb:12-bsb10858300-7 [2020. szeptember 20.]

34. HAYES, Robert M.: The history of library and information science: a commentary. $=$ The Journal of Library History, Vol. 20. No. 2. 1985. 173-178. p. Forrás: www.jstor.org/stable/25541596 [2020. szeptember 20.]

35. iSchools. Forrás: https://ischools.org [2020. szeptember 20.]

36. LISA: Library and Information Science Abstracts. ProQuest. Forrás: https:/ /about.proquest. com/products-services/lisa-set-c.html [2020. szeptember 20.] Érdemes felsorolni főbb tartalmi gyűjtőkörét: Artificial intelligence; Book reviews; CD-ROMs; Computer science applications; Information centres; Information management; Information science; Information storage; Information technology; Internet technology; Knowledge management; Librarianship; Libraries and archives; Library management; Library technology; Library use and users; Medical information; Online information retrieval; Publishing and bookselling; Records management; Telecommunications; Technical services; World Wide Web.

37. LUGYA, Fredrick K.: What counts as a science and discipline in library and information science? = Library Review, Vol. 63. No. 1/2. 2014. 138-155. p. Forrás: https://doi. org/10.1108/LR-08-2013-0103 [2020. szeptember 20.]

38. HJØRLAND, Birger: Library and information science: practice, theory, and philosophical basis. = Information Processing and Management, Vol. 36. No. 3. 2000. 501-531. p. Forrás: https://doi.org/10.1016/S0306-4573(99)00038-2 [2020. szeptember 20.] és BAWDEN, David - ROBINSON, Lyn (ed.): Introduction to Information Science. London, Facet Publishing. 2012.

39. How To Spot Fake News. IFLA. Forrás: https://www.ifla.org/publications/node/11174 [2020. szeptember 20.] és How to Spot Fake News - COVID-19 Edition. IFLA. Forrás: https://www.ifla.org/publications/node/93015 [2020. szeptember 20.] 
A KÖNYVTÁR- ÉS INFORMÁCIÓTUDOMÁNY, VALAMINT A KÖNYVTÁROSKÉPZÉS...

40. AUDUNSON, Ragnar A.: Do we need a new approach to library and information science? = Bibliothek Forschung und Praxis, Bd. 42. H. 2. 2018. 357-362. p. Forrás: https://doi.org/ 10.1515/bfp-2018-0040 [2020. szeptember 20.]

41. IFLA Trend Reports. Forrás: https://trends.ifla.org [2020. szeptember 20.]

42. Issues and Trends. State of America's Libraries Report 2020. American Library Association, April 12, 2020 Document ID: d84a214b-06f9-4f29-9f7a-f24b9f80714e Forrás: http://www. ala.org/news/state-americas-libraries-report-2020/issues-trends [2020. szeptember 20.]

43. KISZL Péter: Ki viszi át...? A könyvtárak társadalmi felelősségvállalása a digitális korban. = Tudományos és Műszaki Tájékoztatás, 64. évf. 1. sz. 2017. 1-23. p. Forrás: https://tmt. omikk.bme.hu/tmt/article/view/774 [2020. szeptember 20.]

44. MOLNÁR Gyöngyvér - TURCSÁNYI-SZABÓ Márta - KÁRPÁTI Andrea: Digitális forradalom az oktatásban - perspektívák és dilemmák. = Magyar Tudomány, 181. évf. 1. sz. 2020. 56-67. p. Forrás: http://www.doi.org/10.1556/2065.181.2020.1.6 [2020. szeptember 20.]

45. Building strong LIS education: a call to global and local action - an IFLA BSLISE working group white paper. Cape Town, University of Cape Town Libraries. 2018. Forrás: http:// dx.doi.org/10.15641/0-7992-2542-6 [2020. szeptember 20.]

46. Whitepaper: the value of American Library Association-Accredited Master's Programs. American Library Association, September 27, 2016. Document ID: 95601e40-ef3e-e954-b574692309a6749f Fossá: http://www.ala.org/educationcareers/value [2020. szeptember 20.]

47. PERCELL, Johnna [et al.] (ed.): Re-envisioning the MLS: perspectives on the future of library and information science education. Bingley, Emerald Publishing Limited, 2018. (Advances in Librarianship, 44A) Forrás: https://doi.org/10.1108/S0065-2830201844A [2020. szeptember 20.] és PERCELL, Johnna [et al.] (ed.): Re-Envisioning the MLS: perspectives on the future of library and information science education. Bingley, Emerald Publishing Limited, 2018. (Advances in Librarianship, 44B) Forrás: https://doi.org/10.1108/S00652830201844B [2020. szeptember 20.]

48. COGHILL, Jeffrey G. - RUSSELL, Roger G.: Developing librarian competencies for the digital age. Lanham, Roman \& Littlefield, 2017. (Medical Library Association Books)

49. RAJU, Jaya: Future LIS education and evolving global competency requirements for the digital information environment: an epistemological overview. = Journal of Education for Library and Information Science, Vol. 61. No. 3. 2020. 342-356. p. Forrás: https://doi. org/10.3138/jelis.61.3.2019-0088 [2020. szeptember 20.]

50. SAUNDERS, Laura: Core and more: examining foundational and specialized content in library and information science. $=$ Journal of Education for Library and Information Science, Vol. 60. No. 1. 2019. 3-34. p. Forrás: https://doi.org/10.3138/jelis.60.1.2018-0034 [2020. szeptember 20.]

51. Pl.: SAUNDERS, Laura: Identifying core reference competencies from an employers' perspective: implications for instruction. $=$ College \& Research Libraries, Vol. 73. No. 4. 2012. 390-404. p. Forrás: https://doi.org/10.5860/crl-281 [2020. szeptember 20.]

52. ABELS, Eileen G. - HOWARTH, Lynne C. - SMITH, Linda C.: Envisioning our information future and how to educate for it. Boston-Toronto-Champaign, The \#InfoFuture Project, 2017. Forrás: http://publish.illinois.edu/whylibraries/files/2019/10/abels2017-WhitePaper_Abels_Howarth_Smith_Final_Aug28.pdf [2020. szeptember 20.] 
53. SAUNDERS, Laura: Professional perspectives on library and information science education. = Library Quarterly, Vol. 85. No. 4. 2015. 427-453. p. Forrás: https://doi. org/10.1086/682735 [2020. szeptember 20.]

54. ROY, Loriene - HALLMARK, Elizabeth - POLACEK, Kelly M.: Cool jobs: expanding the place of the library instruction curriculum to assist graduates in preparing students for atypical work environments. = Reference \& User Services Quarterly, Vol. 55. No. 1. 2015. 25-29. p. Forrás: https://www.jstor.org/stable/refuseserq.55.1.25 [2020. szeptember 20.]

55. Financial literacy education in libraries: guidelines and best practices for service has been created by a working team drawn from the Business Reference and Services Section (BRASS) of RUSA, under the direction of an advisory group of experts in financial literacy. The final document was approved by the RUSA Board on September 29, 2014. Forrás: http:// www.ala.org/rusa/sites/ala.org.rusa/files/content/FLEGuidelines_Final_September_2014.pdf [2020. szeptember 20.] és KISZL Péter: Pénzügyi kultúra, vállalkozásfejlesztés, képzés: a könyvtár mint a gazdasági fejlődés egyik záloga. In: Valóságos könyvtár könyvtári valóság: Könyvtár- és információtudományi tanulmányok. 2018. i. m. 91-101. p. Forrás: https://doi.org/10.21862/vkkv2018.91 [2020. szeptember 20.]

56. WYMAN, Andrea - IMAMVERDIYEV, Mushvig: Global trends and transformations in library science education. $=$ Information and Learning Science, Vol. 119. No. 3/4. 2018. 215-225. p. Forrás: https://doi.org/10.1108/ILS-11-2017-0110 [2020. szeptember 20.]

57. GOODSETT, Mandi - KOZIURA, Amanda: Are library science programs preparing new librarians? Creating a sustainable and vibrant librarian community. = Journal of Library Administration, Vol. 56. No. 6. 2016. 697-721. p. Forrás: https://doi.org/10.1080/019308 26.2015.1134246 [2020. szeptember 20.]

58. CAMPBELL-MEIER, Jennifer - HUSSEY, Lisa: Exploring becoming, doing, and relating within the information professions. = Journal of Librarianship and Information Science, Vol. 51. No. 4. 2019. 962-973. p. Forrás: https://doi.org/10.1177/0961000618757298 [2020. szeptember 20.]; FRASER-ARNOTT, Melissa A.: Evolving practices and professional identity: how the new ways we work can reshape us as professionals and a profession. = IFLA Journal, Vol. 45. No. 2. 2019. 114-126. p. Forrás: https://doi. org/10.1177/0340035218810960 [2020. szeptember 20.]; FRASER-ARNOTT, Melissa A.: Personalizing professionalism: the professional identity experiences of LIS graduates in non-library roles. = Journal of Librarianship and Information Science, Vol. 51. No. 2. 2019. 431-439. p. Forrás: https://doi.org/10.1177/0961000617709062 [2020. szeptember 20.]

59. FRASER-ARNOT'T, Melissa A.: The value of the MLS or MLIS degree: transferable skills identified by LIS graduates in non-library roles. = The Bottom Line, Vol. 29. No. 3. 2016. 129-141. p. Forrás: https://doi.org/10.1108/BL-03-2016-0015 [2020. szeptember 20.]

60. MONIAROU-PAPACONSTANTINOU, Valentini: Valuing studies in higher education: symbolic means and strategies of students negotiating their position in the library and information science field. $=$ Journal of Librarianship and Information Science, Vol. 52. No. 1. 2020. 306-314. p. Forrás: https://doi.org/10.1177/0961000618799530 [2020. szeptember 20.]

61. VÉRTESY Miklós: Könyvtárosegyesületünk fél évszázada (1935-1972). = Könyvtáros, 37. évf. 3. sz. 1987. 166. p.

62. Informatikus könyvtáros BA. Végzés utáni kilátások (DPR AAE, 2015/2016-ban végzettek 2017. decemberi, 2018-ban egységesített adatai) Forrás: https://www.felvi.hu/ 
A KÖNYVTÁR- ÉS INFORMÁCIÓTUDOMÁNY, VALAMINT A KÖNYVTÁROSKÉPZÉS...

felveteli/szakok_kepzesek/szakleirasok/!Szakleirasok/index.php/szak/42/vegzes_utani_ kilatasok [2020. szeptember 20.] és Könyvtártudomány MA. Végzés utáni kilátások (DPR AAE, 2015/2016-ban végzettek 2017. decemberi, 2018-ban egységesített adatai) Forrás: https://www.felvi.hu/felveteli/szakok_kepzesek/szakleirasok/!Szakleirasok/index.php/ szak/234/vegzes_utani_kilatasok [2020. szeptember 20.] Vö. 395900 forint volt a bruttó átlagkereset. Gyorstájékoztató. Keresetek, 2020. január-július. KSH. Forrás: https://www. ksh.hu/docs/hun/xftp/gyor/ker/ker2007.html [2020. szeptember 20.]

63. Mikrocenzus 2016. 13. A foglalkozások presztízse. Budapest, Központi Statisztikai Hivatal, 2018. 9. p. Forrás: https://www.ksh.hu/docs/hun/xftp/idoszaki/mikrocenzus2016/ mikrocenzus_2016_13.pdf [2020. szeptember 20.]

64. Az informatikus könyvtáros BA abszolutóriumot szerzett hallgatók munkahelyének szektora képzés vége tanéve szerint 2015-16. (DPR AAE 2017. decemberi, 2018-ban egységesített adatai) Forrás: https://www.diplomantul.hu/adminisztrativ-adatbazisok-egyesitese [2020. szeptember 20.]

65. A könyvtártudomány MA abszolutóriumot szerzett hallgatók munkahelyének szektora képzés vége tanéve szerint 2015-16. (DPR AAE 2017. decemberi, 2018-ban egységesített adatai) Forrás: https://www.diplomantul.hu/adminisztrativ-adatbazisok-egyesitese [2020. szeptember 20.]

66. ESZENYINÉ BORBÉLY Mária: A felsőfokú könyvtárosképzés szerepe a hallgatók digitális kompetencia-állapotának fejlesztésében. In: Információközvetítés és közösségépítés multifunkciós könyvtári hálózatok. i. m. 303-315. p. Forrás: https://doi.org/10.21862/ infkoz.303 [2020. szeptember 20.]

67. The Digital Economy and Society Index (DESI). European Commission. Forrás: https:// ec.europa.eu/digital-single-market/en/digital-economy-and-society-index-desi [2020. szeptember 20.] Itt említhetjük még: Human Development Index (HDI). United Nations Development Programme (UNDP). Forrás: http://hdr.undp.org/en/content/human-development-index-hdi [2020. szeptember 20.]

68. MOORE, Jennifer - ELKINS, Aaron - BOELENS, Helen: Libraries on the move: by land, by sea, and by air. In: Farmer, Lesley (ed.): International Association of School Librarianship (IASL) Conference 2017 Proceedings. Long Beach. 213-221. p. Forrás: https://doi. org/10.29173/ias17167 [2020. szeptember 20.]

69. HORVÁTH Tibor: A könyvtár- és információtudomány tartalmi értelmezhetőségének problémái. = Könyv, Könyvtár, Könyvtáros, 8. évf. 11. sz. 1999. 15. p. Forrás: http://epa.oszk. hu/01300/01367/00119/pdf/02konyvtar.pdf [2020. szeptember 20.]

70. ALLINSON, Gordon [et al.]: Economic impact evaluation of the British Library Business \& IP Centre National Network. July 2019. London, The British Library, 2019. Forrás: https://www. bl.uk/britishlibrary/ /media/bl/global/business $\% 20$ and $\% 20 \mathrm{ip} \% 20$ centre/documents/ reports $/$ ers $\% 20 \mathrm{bipc}^{2} \% 20$ network $\% 20$ economic $\% 20$ impact $\% 20$ final $\% 20$ report $\% 20$ july $\% 20$ 2019.pdf?la=en\&hash=C35C5A3AA850C6D5B6BED9A807BBA572 [2020. szeptember 20.] és ALLINSON, Gordon [et al.]: Innovating for Growth Phase 2 (2016-19) interim evaluation (2020). Final report. London, The British Library. 2020. Forrás: https://www.bl.uk/ britishlibrary/ /media/bl/global/business $\% 20$ and $\% 20 \mathrm{ip} \% 20$ centre/documents/reports/ innovating $\% 20$ for $\% 20$ growth $\% 20201619 \% 20$ final $\% 20$ report $\% 20$ accessibility $\% 20$ friendly.pd f?la=en\&hash=6435C2A64E391DC95B98381B5AE3BB88 [2020. szeptember 20.] 


\section{KISZL PÉTER}

71. „The price of greatness is responsibility.” Forrás: CHURCHILL, Winston S.: The gift of a common tongue. Harvard, September 6, 1943. International Churchill Society. Forrás: https:// winstonchurchill.org/resources/speeches/1941-1945-war-leader/the-price-of-greatnessis-responsibility [2020. szeptember 20.]

Kiszl Péter - könyvtáros és közgazdász végzettségű habilitált egyetemi docens, az ELTE BTK Könyvtár- és Információtudományi Intézetének igazgatója, az Információtudományi, valamint a Könyvtártudományi Tanszék és a Könyvtártudományi Doktori Program vezetője, az informatikus könyvtáros BA és a könyvtártudomány MA szak felelőse. Kutatási területei: információ- és tudásmenedzsment, üzleti információ, pénzügyi kultúra és a könyvtárak, könyvtár- és információtudományi képzések fejlesztése. ORCID: 0000-0003-2992-295X 